WellBeing International

WBI Studies Repository

10-1981

\title{
Activity of Moose and White-Tailed Deer at Mineral Springs
}

D. Fraser

Ontario Ministry of Natural Resources

H. Hristienko

Ontario Ministry of Natural Resources

Follow this and additional works at: https://www.wellbeingintlstudiesrepository.org/socbeh

Part of the Animal Studies Commons, Behavior and Ethology Commons, and the Comparative Psychology Commons

\section{Recommended Citation}

Fraser, D., \& Hristienko, H. (1981). Activity of moose and white-tailed deer at mineral springs. Canadian Journal of Zoology, 59(10), 1991-2000.

This material is brought to you for free and open access by WellBeing International. It has been accepted for inclusion by an authorized administrator of the WBI Studies Repository. For more information, please contact wbisr-info@wellbeingintl.org.

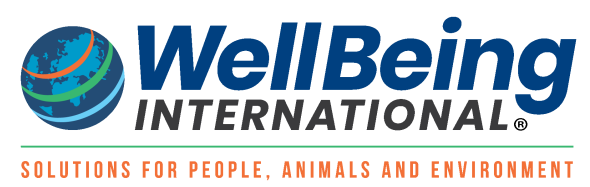




\title{
Activity of Moose and White-Tailed Deer at Mineral Springs
}

\author{
D. Fraser and $\mathrm{H}$. Hristienko \\ Ontario Ministry of Natural Resources
}

\begin{abstract}
Activity of moose (Alces alces) and white-tailed deer (Odocoileus virginianus) was studied at two natural mineral springs (licks) in Ontario during the springtime and summer of 1977 to 1980. Most adult moose appeared to use a lick during a single 1- to 5-day period in a year; some returned at intervals during the season; and all seemed drawn principally by the mineral-rich water. Some young moose remained in the lick vicinity for 3 weeks or more, and often wandered in and out of the licks, grazing herbage as well as drinking. This suggested a social as well as a nutritional attraction for young moose. Activity of both moose and deer increased after leaf flush. Adult male moose used licks most heavily in late May and early June, adult females in middle and late June. Use by young animals was more variable, but all moose activity declined in late June when aquatic feeding became common. Deer continued to use licks heavily until mid-July. Evidently the $\mathrm{Na}$ hunger that motivates lick use is related to spring phenology and wanes during the summer. Social and other behaviour seen at licks is described.
\end{abstract}

\section{Introduction}

Natural mineral licks that attract wildlife are among nature's special places, and have excited the curiosity of naturalists and sportsmen for many years. Despite some continuing controversy (Hanson and Jones 1976, p. 256), most recent studies of licks have concluded that $\mathrm{Na}$ is the principal attraction for wildlife (Hebe and Cowan 1971; Knight and Mudge 1967; Weeks 1978). Selection experiments at licks have shown a specific appetite for $\mathrm{Na}$ among wild ruminants of several species (Stockstad et al. 1953; Fraser and Reardon 1980). Although a number of studies have failed to find high levels of $\mathrm{Na}$ in licks, methods of collecting lick samples may have been at fault (Fraser, Reardon et al. 1980).

Detailed studies of lick use have been made for several ungulate species including white-tailed deer, mule deer (Odocoileus hemionus), elk (Cervus elaphus), mountain goats (Oreamnos americanus), and bighorn sheep (Ovis canadensis) (Carbyn 1975; Weeks 1978; W. McCrory, unpublished data). However, most studies of lick use by moose have given little more than chemical analysis of lick materials. Apart from a 2-month study by Bouchard (1970), some perceptive observations by Shiras (1936), and brief remarks by Murie (1934), Peterson (1953) and a few others, the behaviour of moose at licks has gone largely unrecorded.

Controversy over the role of $\mathrm{Na}$ in moose nutrition is a further reason for studying moose activity at licks. Workers on Isle Royale conclude that moose there suffer an annual $\mathrm{Na}$ depletion in the winter, 
necessitating repletion from special sources, especially aquatic plants, in the summer (Botkin et al. 1973; Jordan et al. 1973). A different view holds that the Na hunger is a feature of the spring and early summer, and is caused by changes in the herbivores' diet at that time (Hebert and Cowan 1971; Weeks and Kirkpatrick 1976).

The following study attempted to describe the behaviour of moose, and coincidentally of white-tailed deer, at two natural mineral licks in Ontario. Special attention was given to the correspondence between lick use and spring green-up as an indication of whether lick use is a response to chronic Na depletion or to a more immediate change in the vegetation.

\section{Study area}

Observations were made at two natural licks located $7 \mathrm{~km}$ apart in Sibley Provincial Park, a 243-km² area of principally boreal forest on a peninsula on the north shore of Lake Superior $\left(48^{\circ} 25^{\prime} \mathrm{N}, 88^{\circ} 47^{\prime} \mathrm{W}\right)$. The park supports conspicuous populations of moose, white-tailed deer, black bears (Ursus americanus), and smaller mammalian species. Licks were located about $400 \mathrm{~m}$ from secondary roads and received little or no human traffic.

Fig. 1. Na content (ppm) of water samples collected from the north source of the Perry Bay lick and the main source of the Marie Louis lick, various dates in 1977 to 1980.

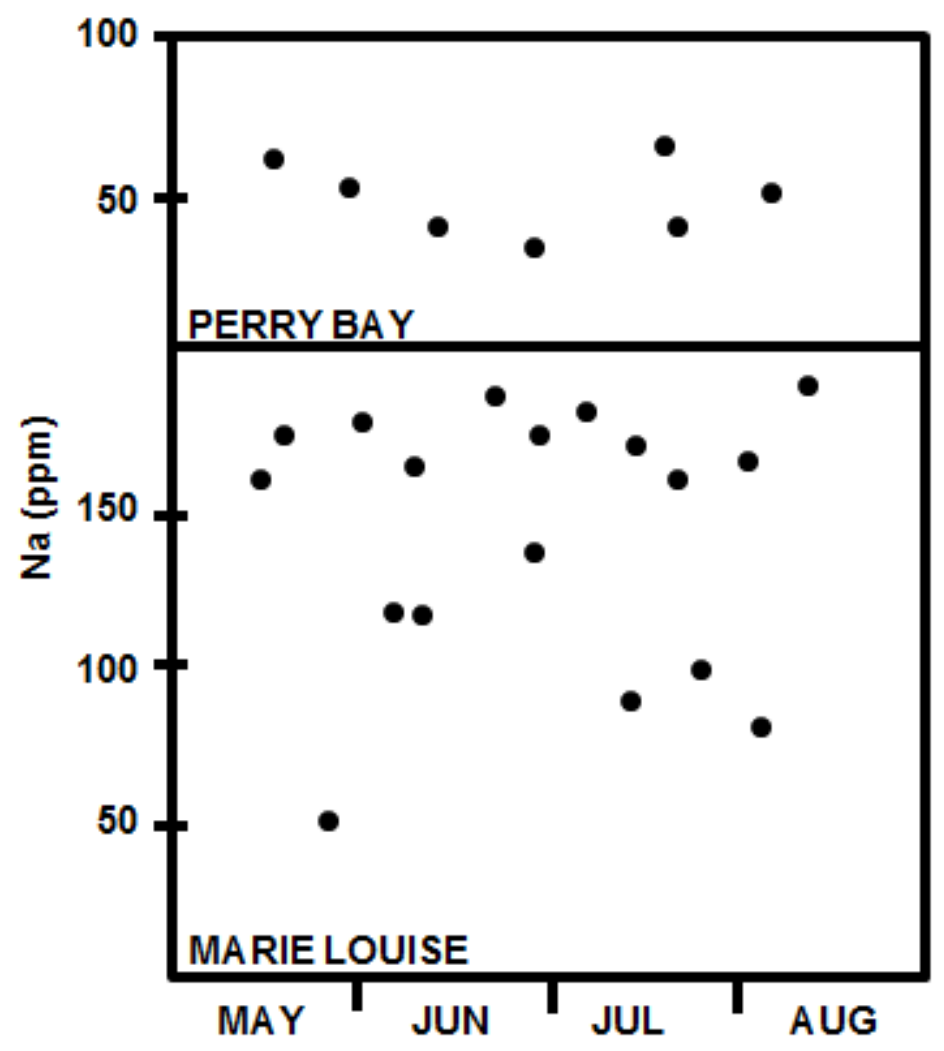

The Marie Louise lick is an area of $200 \mathrm{~m}^{2}$ of bare mud, soil, and stones, devoid of vegetation presumably because of intense animal activity. The lick is centred around several small puddles with water typically containing 120 to $180 \mathrm{ppm} \mathrm{Na}$, fed by a slow-seeping spring. Temporary puddles of more dilute mineral water are scattered throughout the lick. Several well developed animal trails radiate from the site. 
The Perry Bay lick consists of two adjacent areas of largely unvegetated mud and soil, each about 350

$\mathrm{m}^{2}$. One includes a visible jet of water with a $\mathrm{Na}$ content of about $50 \mathrm{ppm}$ (called the north source). The other is centred on a muddy area with small puddles of water containing about $70 \mathrm{ppm} \mathrm{Na}$, thought to be fed by a very slow seepage of mineral-rich water (south source). A small stream fed by the north source flows through the site, and puddles of mineral water occur throughout the lick. Water samples collected from the licks on various dates between 1977 and 1980 showed some fluctuation in Na content, but no systematic change over the season (Fig. 1). A few anomalous low values at the Marie Louise lick may reflect contamination of spring water with surface water that collected periodically in the lick.

Bedrock in the area consists of late Precambrian sediments with an extensive fracture system. The mineral springs are thought to be fed by water collecting locally in topographically higher places, filtering through the fracture system, and dissolving evaporite minerals from the bedrock.

Typical lake and stream water in the area has a Na content of 1 to $4 \mathrm{ppm}$. In addition to its high levels of $\mathrm{Na}$, the lick water is also rich in $\mathrm{Ca}, \mathrm{Mg}, \mathrm{K}$, and $\mathrm{Cl}$, but a selection experiment involving moose and deer at the Marie Louise lick showed a specific hunger only for $\mathrm{Na}$ (Fraser and Reardon 1980).

\section{Methods}

Information was gathered through direct observation of the licks in 1977 to 1980 (details in Table 1). In 1977, most observations were concentrated in four periods (22 May - 5 June, 19 June - 8 July, 19 July 4 August, and 13 August - 5 September) to coincide with observations on aquatic feeding not reported here. Between 10 and 21 3-h watches were scheduled in each period to give approximately equal coverage during the daylight hours of 0600 to 2100 . In 1978, observations averaged about $50 \mathrm{~h} /$ week from mid-May to the end of July, and continued at about $20 \mathrm{~h} /$ week from August to early October. In 1979 and 1980, observations were done only from mid-May to mid-July because there had been very little lick use later in the summer during both previous years. About $25 \mathrm{~h}$ were scheduled per week at each lick, but only the Marie Louise lick was studied in 1980 because of shortage of staff time. In 1978 to 1980, observations were made in 4- to 6-h shifts which gave approximately equal coverage from 0700 to 2100. In addition, observers occasionally visited the licks for other reasons and noted any incidental sightings of animals.

In 1977 the observers sat on the ground in fixed locations 20 and $30 \mathrm{~m}$ from the main source at the Marie Louise and Perry Bay licks, respectively. In 1978 to 1980, a specially designed tent was erected in early May, 5 to $20 \mathrm{~m}$ from the mam source at each lick. The observer sat on a swivel chair and watched through clear plastic or screen windows at head height on all sides of the tent. In this way only the observer's head was visible from outside.

During watches, the observer recorded the sex and age class and the time of arrival and departure of all moose. Photographs were frequently taken, and details of antlers, bell, and distinguishing markings were noted on a standard form. These were then used to help estimate the number of different individuals that used a lick during the year. Two adult bulls of distinctive appearance (called Lewis and D.P.) were recognized at the Marie Louise lick in all 4 years, and three other bulls in 2 successive years each. Notes were also made on the animals' ingestive behaviour (drinking, grazing, etc.), all movements in and out of the lick area, places and times of urination, plus detailed notes on social and other behaviour when possible. For analysis, the length of a visit was defined as the time the animal spent in the actual lick area of unvegetated soil and mud. Repeated visits by the same animal were counted separately if $1 \mathrm{~h}$ had elapsed with the animal out of view. Visits by white-tailed deer proved sufficiently numerous early in 1977 that they were recorded in the same manner as moose sightings in the rest of 1977 and in 1978 to 1980. 
Table 1. First and last dates and number of hours of observation at the two mineral licks in the 4 years of the study, and date of leaf flush of trembling aspen (Populus tremuloides) based on degree-day calculations.

\begin{tabular}{|ccccc|}
\hline & & \multicolumn{2}{c|}{ Observation (h) } & \\
\cline { 3 - 4 } Year & Period & Marie Louise & Perry Bay & Leaf flush date \\
\hline 1977 & 22 May - 5 Sept. & 194 & 188 & 7 May \\
1978 & 16 May - 7 Oct. & 360 & 415 & 18 May \\
1979 & 8 May - 18 July & 228 & 202 & 28 May \\
1980 & 13 May - 21 July & 211 & 0 & 1 May \\
\hline
\end{tabular}

Initially, moose older than calves were classed as yearling or adult on the basis of body and antler size. However, there was some doubt concerning the age of some small-bodied moose. Males were therefore classed as "young," rather than "adult," if their developing antlers were simple spikes no more than half of ear length in May and no more than ear length in June to August. The young category included all distinctly small-bodied males and excluded males with any broadening of the bell. Females of similar body size were also classed as young. Initially deer were judged as yearling or adult on the basis of body size. By midsummer, however, the distinction could no longer be made with certainty.

A cafeteria selection experiment, reported by Fraser and Reardon (1980) and Fraser and Hristienko (unpublished data), was conducted at the Marie Louise lick in 1978 to 1980. On most days, five pails anchored in the lick area were each furnished with $1 \mathrm{~L}$ of solution. Some solutions were Na salts at $0.1 \mathrm{M}$ concentration, and these were normally, consumed by the moose and deer. We believe that the selection experiment had little influence on normal animal activity at the licks. Many moose and deer apparently did not learn to drink from the pails. Animals were seen using the pails in only 13 cases and because of the small volume of fluid offered in the selection experiment, all these animals drank natural lick water during the same visit.

The expected date of leaf flush of trembling aspen (Populus tremuloides) was calculated for all 4 years by the degree-day method of Stewart et al. (1977) using data from the weather station at Thunder Bay, 30 $\mathrm{km}$ to the west. Notes on leaf flush of major browse species were kept in the study area during 1978 to 1980 and largely confirmed the degree-day calculations in those years.

\section{Results}

Moose and deer approached the licks from almost every direction, often using well developed trails. Moose of all age and sex groups entered the lick directly on arriving, without apparent hesitation in most cases (68 of the 103 cases in which the behaviour was recorded). In the remaining cases, the animal waited from 1 to $40 \mathrm{~min}$ (mean $\pm \mathrm{SE}, 9 \pm 2 \mathrm{~min}$ ) before using the lick. During this interval, some moose stood quietly among the trees at the lick edge, looking about and sniffing the air. Others circled among the trees, walking several times to the lick edge, and then retreating.

Deer appeared hesitant when entering the lick in many cases (29 of 50), delaying 2 to 52 min (mean \pm $\mathrm{SE}, 13 \pm 4 \mathrm{~min}$ ) before using the lick. Like some of the moose, they often stood quietly at the edge of the lick area, looking and sniffing. Some retreated among the trees for several minutes and some "snorted" or stamped the ground several times with one front hoof. Much of the hesitation on entering the lick may have been due to the presence of human observers.

\section{Frequency and duration of visits by moose}

Table 2 summarizes the number and duration of visits for the four main categories of moose. Omitted from the table are three visits by females which could not be assigned to an age class and three brief 
sightings of animals of unknown age or sex which did not use the lick. In most cases, means and standard errors are given for descriptive purposes. However, most differences were not tested for statistical significance because the means include various numbers of repeated observations on the same animals. This would violate the usual assumption of independence in the data.

Table 2. Number of visits to mineral licks during scheduled observation and mean \pm SE duration of visits (minutes), for four categories of moose.

\begin{tabular}{|c|c|c|c|c|c|c|c|c|c|c|}
\hline \multirow[b]{2}{*}{ Category } & \multicolumn{2}{|c|}{ Adult males } & \multicolumn{2}{|c|}{ Adult females } & \multicolumn{2}{|c|}{ Young males } & \multicolumn{2}{|c|}{ Young females } & \multicolumn{2}{|c|}{ All 4 groups } \\
\hline & $N$ & $\begin{array}{l}\text { Duration } \\
\text { (min) }\end{array}$ & $N$ & $\begin{array}{l}\text { Duration } \\
\text { (min) }\end{array}$ & $N$ & $\begin{array}{l}\text { Duration } \\
\text { (min) }\end{array}$ & $N$ & $\begin{array}{c}\text { Duration } \\
\text { (min) }\end{array}$ & $N$ & $\begin{array}{c}\text { Duration } \\
\text { (min) }\end{array}$ \\
\hline Marie Louise Lick & 54 & $28.9 \pm 2.1$ & 19 & $27.5 \pm 5.2$ & 26 & $35.7 \pm 3.9$ & 3 & $29.0 \pm 10.5$ & 102 & $30.3 \pm 1.8$ \\
\hline Perry Bay Lick & 17 & $19.2 \pm 3.7$ & 28 & $26.5 \pm 3.5$ & 26 & $38.5 \pm 8.4$ & 34 & $38.3 \pm 5.0$ & 105 & $32.1 \pm 2.9$ \\
\hline \multicolumn{11}{|l|}{ Both Licks } \\
\hline 1977 & 26 & $22.9 \pm 3.4$ & 21 & $22.6 \pm 4.7$ & 13 & $25.3 \pm 7.4$ & 9 & $36.4 \pm 10.0$ & 69 & $25.0 \pm 2.7$ \\
\hline 1978 & 17 & $23.8 \pm 3.3$ & 25 & $31.3 \pm 3.6$ & 19 & $51.3 \pm 10.1$ & 22 & $37.8 \pm 6.3$ & 83 & $36.1 \pm 3.2$ \\
\hline 1979 & 16 & $30.4 \pm 3.3$ & 1 & 6.8 & 20 & $31.1 \pm 3.9$ & 6 & $38.3 \pm 10.7$ & 43 & $31.3 \pm 2.6$ \\
\hline 1980 & 12 & $33.4 \pm 4.8$ & 0 & ----- & 0 & ----- & 0 & ----- & 12 & $33.4 \pm 4.8$ \\
\hline All visits with use & 71 & $26.6 \pm 1.9$ & 47 & $26.9 \pm 2.9$ & 52 & $37.1 \pm 4.6$ & 37 & $37.6 \pm 4.6$ & 207 & $31.2 \pm 1.7$ \\
\hline All visits without use ${ }^{1}$ & 17 & $0.6 \pm 0.3$ & 11 & 1.10 .9 & 12 & $4.0 \pm 2.5$ & 7 & $4.0 \pm 2.8$ & 47 & $2.1 \pm 0.8$ \\
\hline
\end{tabular}

Note: Visits in which the moose used the lick (drank, ate) are summarized separately for the two licks and 4 years of observation.

${ }^{1}$ Animals entered the lick but did not drink or eat.

The bulk of Table 2 summarizes the 207 visits in which moose used the lick (i.e., performed some ingestive activity). These had a mean \pm SE duration of $31.2 \pm 1.7$ min, with little variation between licks or among years. However, visits tended to be longer and more variable for young moose than for adults. The 47 visits in which the animals entered but did not use the lick (bottom line in Table 2) were usually brief, but tended to be longer for young moose than for adults. The eight visits by calves accompanying cows lasted $11.3 \pm 4.9 \mathrm{~min}$. An exceptionally long, 3-h visit by a young male (more than 4 SD from the mean) was omitted from subsequent analysis. In addition to visits summarized in Table 2, there were 62 incidental sightings of moose at the licks over the 4 years, outside the scheduled observation periods.

Moose used the licks at all times of the day, with little consistent diurnal pattern of activity. In 1977, activity was concentrated during mornings and evenings for all age and sex groups: $70 \%$ of the activity occurred in the periods 0700-1100 and 1700-2000. In other years, however, activity was as common near midday and during the afternoon as at other times. The difference between years is difficult to explain, but it might be related. to the different scheduling of observations in 1977.

There was a pronounced difference between the sexes in the seasonal pattern of moose activity at the licks. Adult males used the licks most heavily in late May and early June and showed a sharp drop in activity by mid-June in most years. For adult females most lick use occurred in middle and late June (Fig. 2).

Lick use by young animals was more variable. At various times, young moose were seen, often in pairs, spending several hours in a lick over a few days. For example, on 17 to 19 May 1978, three young males made seven long visits to the Perry Bay lick (averaging $80 \pm 20 \mathrm{~min}$ ) with two or three moose often present together. Presumably these sporadic concentrations of activity made seasonal regularities less clear. 
Leaf flush was relatively late in 1978 and 1979 (Table 1). In those years, the peak of activity at licks (averaged for the four age and sex classes) occurred in the second 10-day period of June, and in 1979 there was very little activity in May. In 1977 and 1980, the 2 years of earlier leaf flush, activity reached a peak in early June and declined thereafter (Table 3). Presumably some of the differences between years are due to differences in the proportion of males and females seen. Unfortunately the data were too sparse to allow separate comparisons by age and sex class.

There was little systematic change over the season in the average length of individual visits. However, moose had slightly shorter visits in July to October $(20.8 \pm 3.4 \mathrm{~min}, n=20)$ than in May and June $(31.5 \pm$ $1.7 \min , n=186)$.

Fig. 2. Time spent in the lick (minutes per hour of scheduled observation) for adult male ( $\bullet$ ) and adult female $(\odot)$ moose by period. Results are confined to visits in which the animal used the lick and are combined for the 4 years. Total number of hours of scheduled observation $(H)$ is shown for each period.

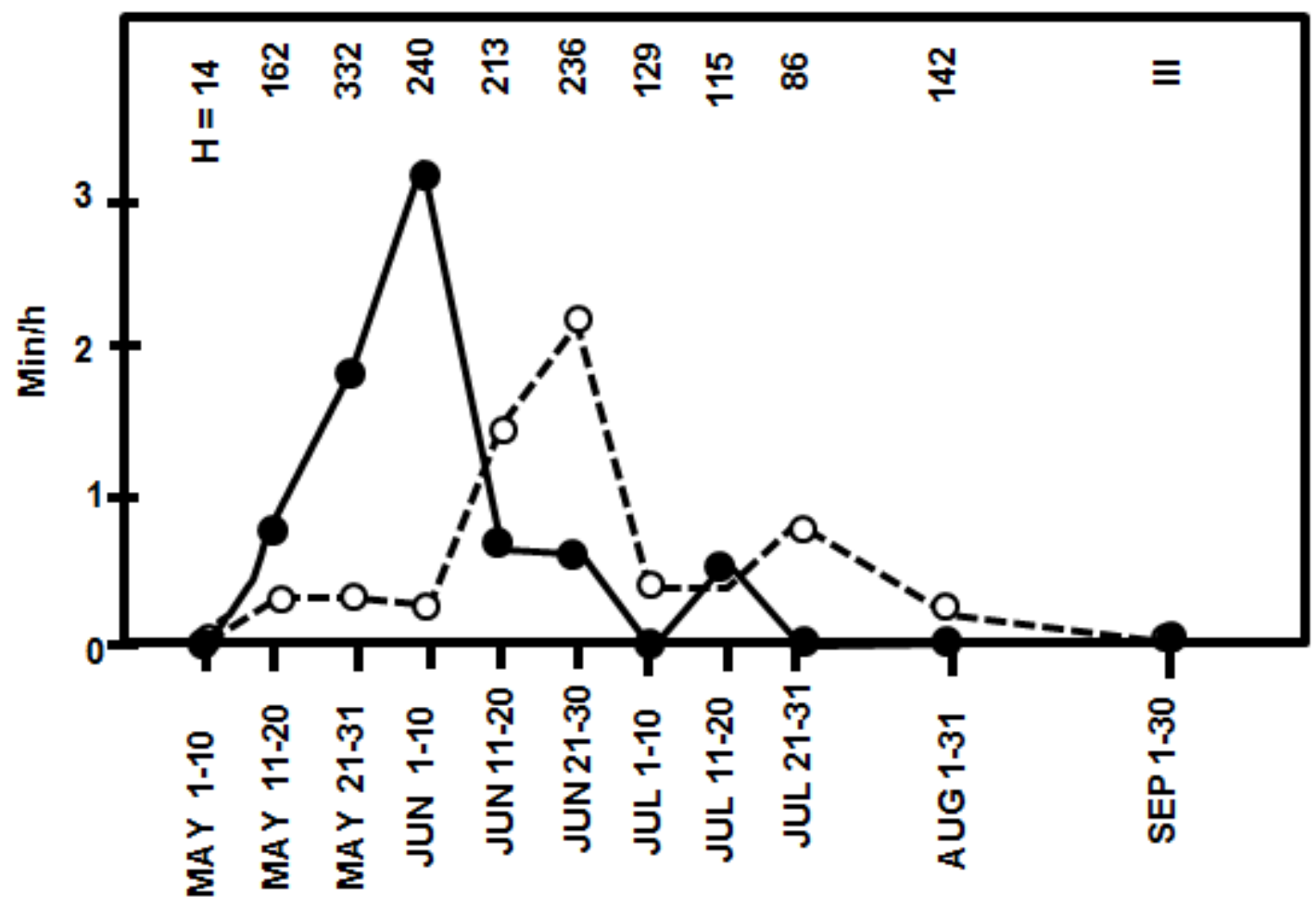

Frequency and duration of visits by deer

In 1978-1980, the years in which complete records were kept on deer, there were 81 visits that involved use of the lick by deer. These had a mean \pm SE duration of $13.3 \pm 1.0 \mathrm{~min}$, with no substantial differences between sexes, licks, or years. The 14 visits by deer which did not use the lick were much more brief $(0.2$ $\pm 0.2 \mathrm{~min}$ ). One fawn, accompanying a doe, visited but did not use the Perry Bay lick. In addition there were 20 incidental sightings of deer at the licks outside scheduled observa-tions and 34 visits were recorded in 1977.

In 1978-1980, deer activity was concentrated during the morning and early afternoon; $75 \%$ of the activity occurred between 0700 and 1400 with the highest level at 1100-1200. In 1977, however, activity was as 
common during the evening (1800-2100) as at other times. The daily pattern of lick use by deer may have been influenced by moose activity, as moose sometimes excluded deer from a lick (see below).

Table 3. Number of hours of observation at licks (hours), and number of minutes spent in the lick by young and adult, male and female moose per hour o observation (minutes per hour) by period in the 4 years.

\begin{tabular}{|c|c|c|c|c|c|c|c|c|}
\hline \multirow[b]{2}{*}{ Period } & \multicolumn{2}{|c|}{1977} & \multicolumn{2}{|c|}{1978} & \multicolumn{2}{|c|}{1979} & \multicolumn{2}{|c|}{1980} \\
\hline & $\mathbf{h}$ & $\mathrm{min} / \mathrm{h}$ & $\mathbf{h}$ & $\mathrm{min} / \mathrm{h}$ & $\mathbf{h}$ & $\mathrm{min} / \mathrm{h}$ & $\mathbf{h}$ & $\mathrm{min} / \mathrm{h}$ \\
\hline $21-31$ May & 94 & 6.69 & 98 & 3.46 & 99 & 1.40 & 42 & 3.47 \\
\hline $1-10$ June & 28 & 10.26 & 81 & 7.63 & 83 & 6.20 & 48 & 3.95 \\
\hline $11-20$ June & 24 & 1.58 & 81 & 10.87 & 71 & 6.68 & 36 & 0.83 \\
\hline $21-30$ June & 80 & 6.44 & 74 & 4.58 & 63 & 1.18 & 19 & 0.00 \\
\hline 1 - 10 July & 21 & 2.49 & 60 & 0.00 & 28 & 0.21 & 20 & 0.00 \\
\hline \multicolumn{9}{|l|}{ Weighted mean } \\
\hline 21 May - 10 July & 247 & 6.16 & 394 & 5.52 & 344 & 3.51 & 165 & 2.21 \\
\hline
\end{tabular}

Fig. 3. Time spent in the lick (minutes per hour of scheduled observation) for all four classes of moose and all deer by period. Results are confined to visits in which the animal used the lick and exclude the 1977 data because complete records on deer were not kept in that year. Total number of hours of scheduled observation in 1978 to $1980(\mathrm{H})$ is shown for each period.

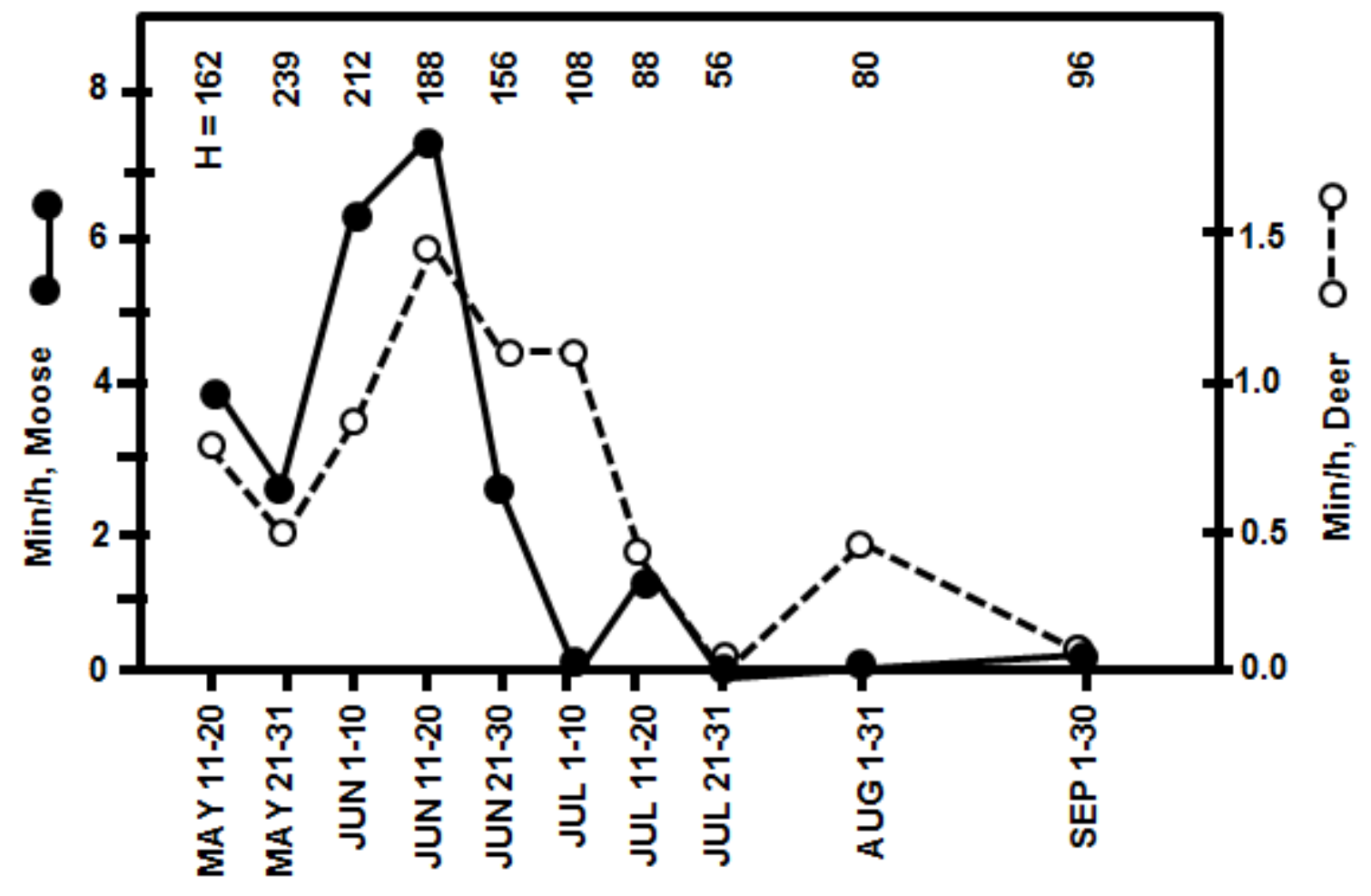

Use of the licks reached a peak in mid-June for deer of both sexes, and declined slowly during late June and July (Fig. 3), in contrast to the earlier decline in moose activity. 
Ingestive behaviour

Drinking water was the main ingestive activity in the licks. It was recorded in 200 of the 207 visits in which moose used the lick and in 104 of 108 visits by deer (Table 4). Other ingestive activities were performed by young moose more than adults, usually in combination with drinking.

While at the lick, both moose and deer alternated between drinking with the head lowered and looking about with the head raised. The behaviour was extremely variable. Moose typically held the head down for 5-30 s and up for 10-120 s; deer typically held the head down for 5-20 s and up for 2-30 s. Moose sometimes appeared to have difficulty lowering the mouth to the water. Some stood with the front legs well apart, some bent one front leg, and some "knelt" on the front tarsal joints.

Table 4. Number of visits in which five ingestive activities were recorded for adult moose, young moose, and deer.

\begin{tabular}{|lccc|}
\hline Activity & Adult moose & Young moose & Deer \\
\hline Drinking & 117 & 83 & 104 \\
Grazing & 12 & 38 & 13 \\
Eating or licking mud & 3 & 9 & 9 \\
Browsing & 1 & 1 & 2 \\
Gnawing sticks & 1 & 1 & 1 \\
\hline
\end{tabular}

At the Marie Louise lick, with its one localized spring source, almost all adult moose drank from the source (44 of 46 cases) and many drank only from the source (33 cases). Most deer drank from the main source as well (31 of 41 cases). The Perry Bay lick had an active flow of water in the north and small pools of more concentrated water in the south. Most moose tested various pools (63 of 81 visits) and many drank at both the north and south ends.

\section{Movements from the lick}

In most cases, especially at the Marie Louise lick, animals left the main drinking area and walked to the forested lick edge one or more times during a visit. Adult moose did this every 18 min, young moose every $29 \mathrm{~min}$, and deer every $9 \mathrm{~min}$ on average. Animals often urinated during these brief excursions out of the lick. At the Marie Louise site, adult moose urinated outside the lick in 36 of the 42 observed instances of urination, young moose in 10 of 16, and deer in 31 of 35 instances.

Some of the brief movements out of the lick appeared to be made for the purpose of urination, as the animal urinated immediately upon reaching the lick edge, and returned to the lick immediately after urinating. In other cases, excursions to the lick edge did not involve urination; the animal simply looked about for a minute or more before returning to the lick.

At the Perry Bay lick, where the mineral-rich water was less localized, animals did not make such conspicuous movements away from the drinking areas before urinating. Adult moose urinated in the trampled lick area in 16 of 26 cases, young moose in 34 of 50 cases, and deer in 7 of 8 cases.

The time elapsed between successive urinations was noted for animals which urinated twice without being out of view in the interval. The mean \pm SE interval was $22 \pm 2$ min for moose (based on 38 cases) and $14 \pm 2$ min for deer (10 cases) with no obvious differences between age and sex classes. 


\section{Behaviour of young moose}

In many cases the behaviour of young moose at the licks appeared less purposeful than the behaviour of adults. For example, a young male, judged to be 1 year old, used the Marie Louise lick on 28 May 1977. Unlike adults, which normally walked directly to the main source, the young bull meandered throughout the lick site, sniffing in numerous places but drinking only once, not from the source. The animal wandered repeatedly from the lick to the forest edge and back, and then fed on some willow (Salix sp.) and grass.

Fig. 4. Number of visits by three individual moose at the Marie Louise lick and number of hours of observation (below), by date in 1979. D.P. and Lewis were adult males, and Necktie was a young male in 1979.

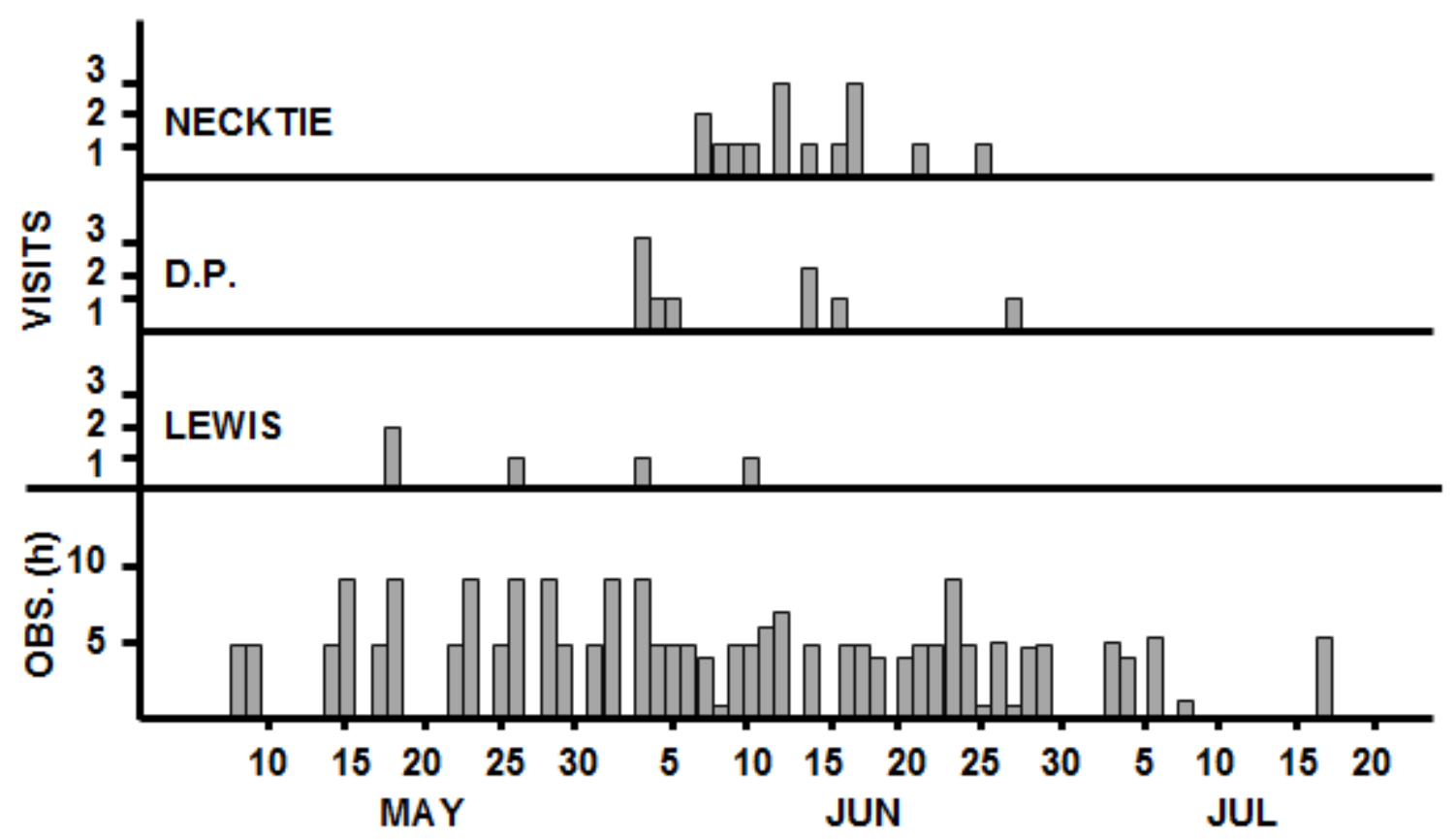

The behaviour of some young moose took on a more purposeful appearance perhaps because of increasing experience. For example, one young bull spent 60 min at the Perry Bay lick on 17 May 1978. It entered the lick four times, drank small amounts from numerous pools at the north and south ends, and ate grass periodically. Five days later, however, it made a single 20-min visit. On arrival it walked directly to the north source, drank exclusively from the source and a few surrounding pools, and ate some grass from the same area.

\section{Competition between animals}

At the Marie Louise lick, moose often appeared to exclude deer or other moose from the preferred source area, or even from the entire lick. On nine occasions a deer remained outside the lick or used pools near the lick edge while a moose used the main source, and twice a moose chased a deer briefly. One cow accompanied by a calf charged at a young bull moose and chased it out of the lick. On four occasions when the adult bull "Lewis" was using the main source, other bulls drank from less preferred parts of the lick. On two of these occasions Lewis made a short charge toward the other animal. 


\section{Behaviour of individual moose}

An estimated six to nine different adult bulls used the Marie Louise lick in 1977 and 1978, five or six in 1979 , and five in 1980. Adult females probably numbered 5 to 10 at the Marie Louise lick in 1977, 4 in 1978, and none in 1979 and 1980. Young moose were estimated at about nine in 1977, seven in 1978, three in 1979, and none in 1980. The total number of moose using the Marie Louise lick was probably 20 to 28 in 1977, and declined to 5 in 1980. Numbers at the Perry Bay lick were thought to be similar and also showed a distinct fall from 1978 to 1979 . However, the preponderance of young animals at the Perry Bay lick made it more difficult to identify animals with confidence.

The only moose known to have used both licks was unusual in both appearance and behaviour. It was an immature bull with deformed, spike antlers and a full winter coat. The bull used the Perry Bay lick for 48 min on 28 May 1978. It drank from various places, especially the spring source, but it also browsed some speckled alder (Alnus rugosa), a species usually rejected by moose, and ate two small dead sticks. Six days later it entered the Marie Louise lick while an adult bull was occupying the source pool. The newcomer wandered in the lick area for 19 min, exploring but never drinking.

Fig. 5. Number of visits by three adult male moose at the Marie Louise lick and number of hours of observation (below), by date in 1980.

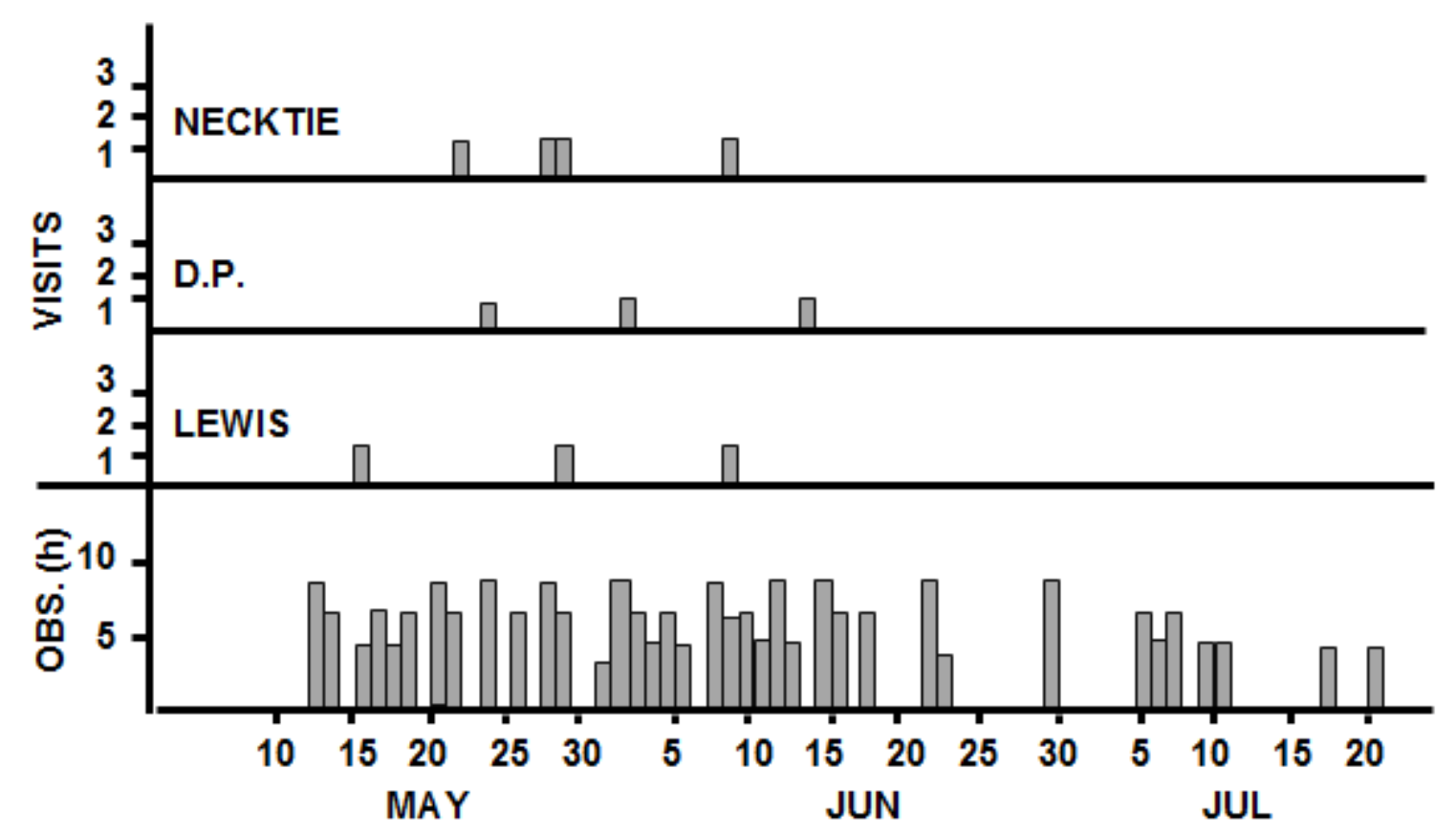

Many individuals appeared to visit a lick repeatedly during one brief period (up to 5 days), with little or no use earlier or later in the season. For example, one adult bull was seen at the Marie Louise lick three times in 1979, all within a 4-day period. However, some adults appeared to make repeated trips to a lick with 8- to 12-day absences between periods of use. In 1979, for example, Lewis was seen twice on May 18 and once each on three subsequent days spaced about 8 days apart. "D.P.," another adult bull, was seen repeatedly during three periods in 1979. The periods lasted from 1 to 3 days and were spaced about 10 days apart (Fig. 4). The same two moose showed similar spacing of visits in 1980 (Fig. 5). In some cases, of course, intervening visits may have occurred outside the scheduled observations. "Necktie" was considered a young male in 1979. In that year it visited the lick repeatedly between 7 and 25 June (Fig. 
4). In 1980, Necktie was of adult size and its visits were spaced at longer intervals, similar to the pattern shown by D.P. and Lewis (Fig. 5).

\section{Discussion}

The moose and deer were evidently attracted to the licks principally by the mineral-rich water. Similar observations were made by Murie (1934) for natural licks on Isle Royale and by Bouchard (1970) for a lick in Quebec. At the Marie Louise lick the animals preferred the source area presumably because the mineral-rich water at the source would be least diluted with surface water (Fraser, Reardon et al. 1980).

In contrast to adults, some young moose remained in the lick vicinity for many days or weeks, wandered in and out of the licks, or remained in the licks without drinking the spring water. This gave the impression that young moose were sometimes drawn to the licks by some nonnutritional factor such as the concentrated activity and scent of other moose. Once attracted to the lick in this way, the animals would then learn to use the water to satisfy a mineral hunger. Studies of other species have also suggested that part of the attraction may be social as well as nutritional (Knight and Mudge 1967; Carbyn 1975).

Although observations were too incomplete to permit firm conclusions, they suggested two different patterns of lick use by adult moose. Some adults appeared to have only one brief (1 to 5 day) stay in the lick area during the season of active use, while others had several periods of lick activity at intervals during the season. Because there were few licks in the area, moose probably did not visit other licks during these intervals. Single annual visits to licks have been noted by Best et al. (1977) for moose in Alberta and by Hebert and Cowan (1971) for mountain goats in British Columbia, but repeated visits were recorded by Carbyn (1975) for elk in Jasper National Park. If ungulates can satisfy their springtime hunger for $\mathrm{Na}$ through one or more brief movements to $\mathrm{Na}$ sources, then a lick can serve numerous animals without many being present at any one time. This may cause casual observers to underestimate the value of such sites to wildlife. Our estimate of 20 to 28 individuals using each lick in the early years of the study is similar to Bouchard's (1970) estimate of 27 moose using a lick in Quebec.

The tendency of moose and deer to leave the Marie Louise lick before urinating is similar to behaviour observed by Bouchard (1970). Since moose seem reluctant to drink urine-contaminated water (D. Fraser and $\mathrm{H}$. Hristienko, unpublished data), movements out of the lick may be purposeful, analogous to horses defecating in certain areas where they do not normally graze (Taylor 1954). Alternatively, the animals may simply be seeking cover or avoiding the rocky surface of the lick before adopting the urination stance. Animals commonly urinated in the Perry Bay lick where the muddy surface afforded surer footing.

Workers on Isle Royale attribute the $\mathrm{Na}$ hunger of moose to a chronic depletion of Na during the winter when the animals feed on woody browse (Jordan et al. 1973). If this were the case, one would expect moose to use licks as soon as the Na-rich water became available in the springtime. Although the licks were not observed in April and early May, the untrampled appearance of the sites in mid-May suggested little earlier activity. The systematic observations usually showed scant use of the licks until late May or early June, by which time the moose were presumably feeding heavily on new leafy vegetation. A similar late start is shown by moose using roadside pools of water rich in highway salt (D. Fraser and E. R. Thomas, unpublished data), by elk at licks in Idaho (Dalke et al. 1965), and by deer at licks in Indiana (Weeks 1978). Furthermore, lick use appeared to be delayed further in years with a slower accumulation of degree-days and later leaf flush. This suggests that the Na hunger is linked to spring phenology.

The hunger could perhaps be caused by a change of diet associated with leaf flush. The greater succulence and higher $\mathrm{K}$ content of the new vegetation may cause wet faeces and an increased loss of $\mathrm{Na}$ in faecal moisture (Hebert and Cowan 1971 ; Weeks and Kirkpatrick 1976). 
Reacclimation to warm weather may also play a role. In becoming acclimatized to cold, laboratory rats show a reduction in muscle tissue with an associated loss of body moisture (Heroux 1958). Moose also show a marked, seasonal decline in weight during the winter (Franzmann et al. 1978), with recovery of weight in the warm season. If the moose's weight gain in the spring and early summer involves an increase in body moisture, then additional $\mathrm{Na}$ might be needed for osmotic reasons. With a Na-poor diet of woody browse, a source of supplementary Na could be important.

Moose activity at the licks declined sharply in late June, about the time when aquatic feeding in the area became common (D. Fraser, unpublished data). Based on wet weights, preferred species of aquatic plants appear to be a richer source of $\mathrm{Na}$ than the lick water, and the aquatics have the additional benefit of supplying moderate levels of energy, protein, and other nutrients. We suspect that moose in our area change from use of licks to aquatic feeding once the preferred plant species have become abundant. Similarly, moose in the Sibley area in 1978 largely stopped drinking dilute, salty water in roadside pools when aquatic feeding became common (Fraser 1979). White-tailed deer, which rarely feed on aquatics in our area, continued to use the licks well into July.

By late July, the attraction to $\mathrm{Na}$ appears to decline in both moose and deer. Neither species makes much use of the licks, aquatic feeding by moose declines sharply (Cobus 1972), and roadside pools of salty water are rarely used. Presumably the seasonal need or hunger for $\mathrm{Na}$ has waned by this time. Despite some variation among species, most North American work shows that an attraction to licks is far more conspicuous in the spring and early summer than at other times (Peterson 1953; Dalke et al. 1965; Carbyn 1975; Weeks 1978).

On average, adult bulls used the licks earlier in the season than did adult cows. A similar predominance of bulls early in the season was noted at aquatic feeding areas by Cobus (1972) and Fraser, Arthur et al. (1980). The presence of young calves might inhibit cows from moving to licks or preferred aquatic habitats and the increased mineral demand of lactation might prolong the $\mathrm{Na}$ hunger later into the summer. Alternatively, adult females may simply develop the $\mathrm{Na}$ hunger later than bulls for other physiological reasons. The sex difference will not likely be understood until the basic causes of the $\mathrm{Na}$ hunger are established.

During the years of the study, there was a distinct decline in the amount of moose activity seen per hour of observation (Table 3) and in the number of individuals using the licks, especially young animals and females. A similar decline in moose activity was also noticed at aquatic feeding areas and roadsides (D. Fraser and $\mathrm{H}$. Hristienko, unpublished data). At the beginning of the study, moose seemed extremely abundant in the park, the limited browse was severely hedged, and some yearling moose, appeared to be abnormally small. The population probably declined substantially during the study. Poor reproduction would account for the declining number of young animals, but the reduced lick use by adult females remains to be explained.

\section{Acknowledgements}

We are grateful to A. Hurley and L. Walters for assistance in the field, to Ministry of Natural Resources staff at Thunder Bay and Sibley Provincial Park' for cooperation in all aspects of the work, and to J. D. Roseborough and C. D. Macinnes for support of the project. A. Perras, F. Dieke, M. Rawlings and staff kindly provided chemical analysis. The possibility that temperature acclimation may contribute to $\mathrm{Na}$ hunger was pointed out to us by Dr. S. Magwood. D. Baggley, T. Bellhouse, and G. Cunningham, and the journal reviewers provided valuable suggestions and assistance with the manuscript. 


\section{References}

BEST, D. A., G. M. LYNCH, and O. J. RONGSTAD. 1977. Annual spring movements of moose to mineral licks in Swan Hills, Alberta. Proc. N. Am. Moose Conf. Workshop, 13: 215-228.

BOTKIN, D. B., P. A. JORDAN, A. S. DOMINSKI, H. S. LOWENDORF, and G. E. HUTCHINSON. 1973. Sodium dynamics in a northern ecosystem. Proc. Natl. Acad. Sci. U.S.A. 70: 2745-2748.

BOUCHARD, R. 1970. Étude préliminaire du comportement de l'orignal dans une vasiere de la Réserve Matane, été 1965. Serv. Faune Qué. Rapp. 5: 235-253.

CARBYN, L. N. 1975. Factors influencing activity patterns of ungulates at mineral licks. Can. J. Zool. 53: 378-384.

COBUS, M. 1972. Moose as an aesthetic resource and their summer feeding behaviour. Proc. N. Am. Moose Conf. Workshop, 8: 244-275.

DALKE, P. D., R. D. BEEMAN, F. J. KINDEL, R. J. ROBEL, and T. R. WILLIAMS. 1965. Use of salt by elk in Idaho. J. Wildl. Manage.29: 319-332.

FRANZMANN, A. W., R. E. LERESCHE, R. A. RAUSCH, and J. L. OLDEMEYER. 1978. Alaskan moose measurements and weights and measurement-weight relationships. Can. J. Zool. 56: 298-306.

FRASER, D. 1979. Sightings of moose, deer, and bears on roads in northern Ontario. Wildl. Soc. Bull. 7: 181-184.

FRASER, D., D. ARTHUR, J. K. MORTON, and B. K. THOMPSON. 1980. Aquatic feeding by moose Alces alces in a Canadian lake. Holarctic Ecol. 3: 218-223.

FRASER, D., and E. REARDON. 1980. Attraction of wild ungulates to mineral-rich springs in central Canada. Holarctic Ecol. 3: 36-40.

FRASER, D., E. REARDON, F. DIEKEN, and B. LOESCHER. 1980. Sampling problems and the interpretation of chemical analysis of mineral springs used by wildlife. J. Wildl. Manage. 44: 623-631.

HANSON, H. C., and R. L. JONES. 1976. The biochemistry of blue, snow and Ross' geese. III. Nat. Hist. Surv. Spec. Publ. No. 1.

HEBERT, D., and I. MCT. COWAN. 1971. Natural salt licks as a part of the ecology of the mountain goat. Can. J. Zool. 49: 605-610.

HEROUX, O. 1958. Weights and composition of muscles of warm- and cold-acclimated rats. Can. J. Biochem. Physiol. 36: 289-293.

JORDAN, P. A., D. B. BOTKIN, A. S. DOMINSKI, H. S. LOWENDORF, and G. E. BELOVSKY. 1973. Sodium as a critical nutrient for the moose of Isle Royale. Proc. N. Am. Moose Conf. Workshop, 9: 13-42.

KNIGHT, R. R., and M. R. MUDGE. 1967. Characteristics of some natural licks in the Sun River area, Montana. J. Wildl. Manage. 31: 293-299.

MURIE, A. 1934. The moose of Isle Royale. Univ. Mich., Mus. Zool. Misc. Publ. No. 25. 
PETERSON, R. L. 1953. Studies of food habits and the habitat of moose in Ontario. Contrib. R. Ont. Mus. Zool. Palaeontol. No. 36.

SHIRAS, G. 1936. Hunting wildlife with camera and flashlight. Vol. 1 and 2. National Geographic Society, Washington, DC.

STEWART, R. R., R.R. MACLENNAN, and J. D. KINNEAR. 1977. The relationship of plant phenology to moose. Sask. Dep. Tourism Renewable Resour. Tech. Bull. No. 3.

STOCKSTAD, D. S., M. S. MORRIS, and E. C. LORY. 1953. Chemical characteristics of natural licks used by big game animals in western Montana. Trans. North Am. Wildl. Conf. 18: 247-258.

TAYLOR, E. L. 1954. Grazing behaviour and helminthic disease. Br. J. Anim. Behav. 2: 61-62.

WEEKS, H.P., JR. 1978. Characteristics of mineral licks and behavior of visiting white-tailed deer in southern Indiana. Am. Midi. Nat. 100: 384-395.

WEEKS, H.P., JR., and C. M. KIRKPATRICK. 1976. Adaptations of white-tailed deer to naturally occurring sodium deficiencies. J. Wildl Manage. 40: 610-625. 